\title{
Peniophora junipericola (Aphyllophorales, Corticiaceae): distribution and spore variability
}

\author{
E. PARMASTO and I. PARMASTO
}

PARMASTO, E. \& PARMASTO, I. 1992: Peniophora junipericola (Aphyllophorales, Corticiaceae): distribution and spore variability. - Karstenia 32:13-16.

Peniophora junipericola J. Erikss. is a possibly xerothermic species. It is very common on the western islands of Estonia and near the Baltic Sea in Latvia, frequent in some eastern parts of Sweden, and rare or very rare elsewhere. The spore size and form do not differ significantly in specimens collected in Estonia, the Crimea, the Tianschan or other localities.

Key words: Peniophora junipericola, variability of basidiospores, xerothermic distribution.

Erast Parmasto and Ilmi Parmasto, Institute of Zoology and Botany, Estonian Academy of Sciences, 21 Vanemuise St., 202400 Tartu, Estonia (U.S.S.R.)

Peniophora is a genus with a rather large number of closely related species. For the differentiation of the related species incompatibility tests are sometimes essential, but it is also possible to find some micromorphological characters which enable distinction of sibling species in dry material.

One of the species is Peniophora junipericola $\mathrm{J}$. Erikss., which was distinguished from $P$. pithya 40 years ago (Eriksson, 1950: 47, 52). It was found to be incompatible with $P$. pithy $a$ and is differentiated from that species by the lack of sulfocystidia, larger spores and rolling-off margins in older basidiocarps.

\section{Host relationships and distribution}

Most of the Peniophora species are specialized on the wood of one tree genus, but are sometimes found on others, too. In Europe $P$. junipericola has been found mainly on dead, still attached branches or dead trunks of Juniperus communis. In the Northwest Caucasus, in Spain and in the Crimea, it mainly inhabits $J$. oxycedri, but also grows on J. excelsa in the Crimea, and on J. semiglobatus in the Tianschan. The other Peniophora species found on Juniperus communis are $P$. pithya (in Sweden) and P. cinerea (Fr.) Cke. (in the Netherlands), but they are extremely rare on this substrate. Amylostereum laevigatum (Fr.) Boid. is ecologically similar to $P$. junipericola, but grows on trunks lying on the ground or at the base of dead trunks of Juniperus. Peniophora junipericola is found only exceptionally on such substrates in places where the species is very common (for example, on the island Vilsandi in Estonia).

Most of the Aphyllophorales which are known to have a distinctly limited distribution are either rare species or have been described recently and may be found in further places later. One of the few exceptions is $P$. junipericola, which has a well-defined area in North Europe, where it is very common, and a few scattered localities in Southwest Europe and Asia.

In Estonia (Fig. 1) this species is very common on the western islands, occurring on Saaremaa (Ösel), Hiiumaa (Dagö) and Muhu (Mohn), and the small islands Vilsandi (Felsland), Abruka (Abro), Vormsi (Worms) and Kessulaid; it is common on the West and Northwest Estonian mainland up to $50 \mathrm{~km}$ from the Baltic Sea, and scattered or in some places common in North Estonia near the Gulf of Finland (up to $25 \mathrm{~km}$ from the seashore). There are also a few scattered localities in Central Estonia, where only single specimens have been found. On the island Ruhnu, lying in the centre of Riga Bay, about $40 \mathrm{~km}$ from the mainland (Kolka Peninsula, Latvia), the fungus was found abundantly in the southwestern part, viz. in a Juniperus stand, damaged by fire and exposed to western winds, and was represented by 


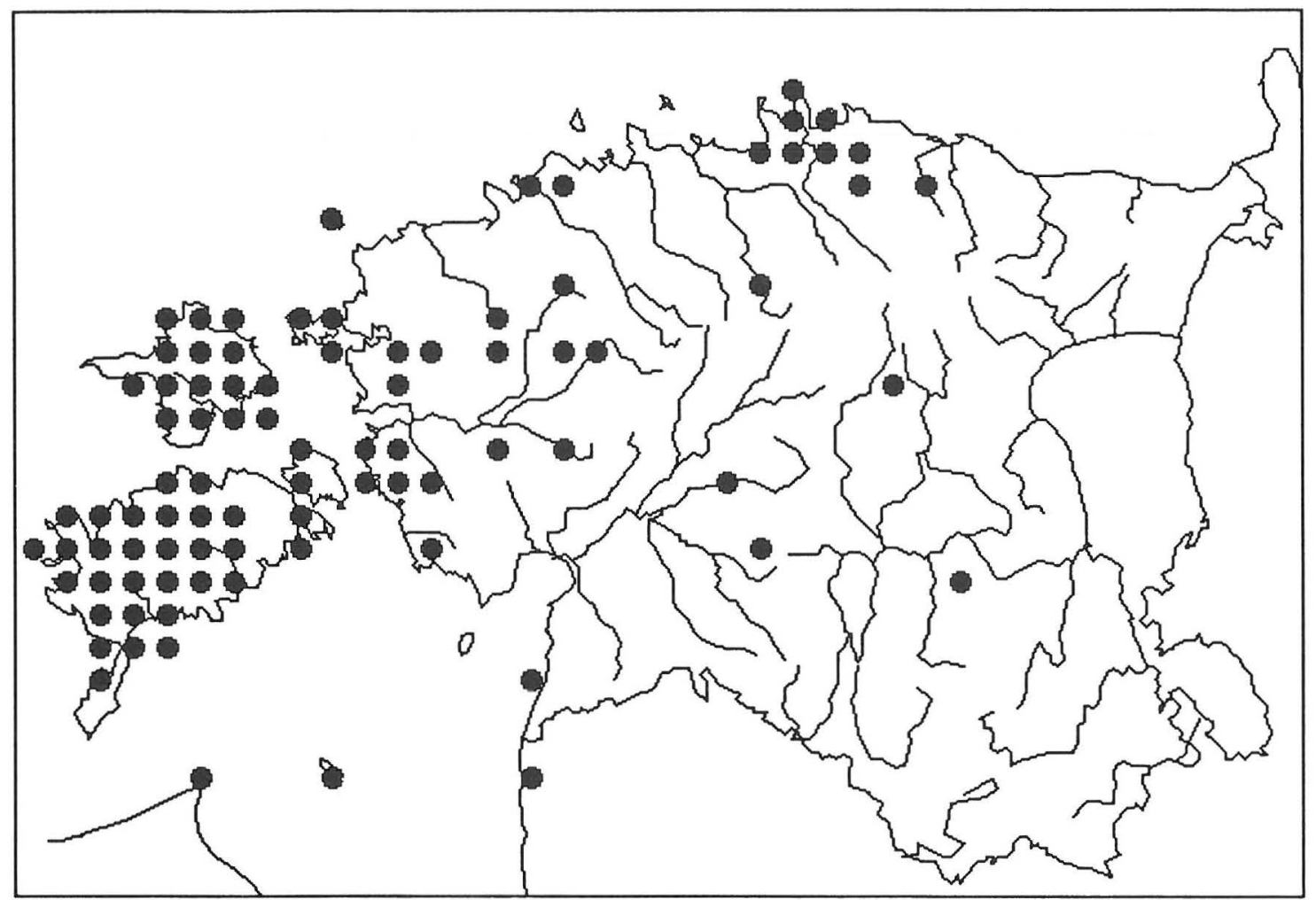

Fig. 1. The distribution of Peniophora junipericola in Estonia and North Latvia.

some rare specimens in other parts of the island. This distribution on Ruhnu possibly indicates that the species has colonized this small island fairly recently.

The most favorable places for the fungus in Estonia are dry pine forests, mainly of alvar type, with abundant stunted Juniperus trees up to $5 \mathrm{~m}$ tall. Near the seashore (up to $3 \mathrm{~km}$ from the sea) it may also be found on dry treeless alvars, on small Juniperus bushes.

In Estonia more than 1000 square kilometers of the country are covered with Juniperus stands (Kaar 1965); the tree is more or less common all over Estonia, including several regions in the southeast, and dead bushes or trees are numerous everywhere. Consequently, the rather limited distribution of $P$. junipericola in Estonia is not caused by a lack of suitable substrata, but by some other factors.

In Latvia $P$. junipericola is more or less common near the Baltic Sea from Kolkasrags in the north to the Lithuanian boundary in the south. One locality is also known near Riga, not far from the shore of Riga Bay.
In the interior of both Latvia and Estonia, however, the species has been searched for without result in many places and for many years.

In Sweden $P$. junipericola seems to be frequent in the eastern parts of the country from Blekinge to Uppland and on Öland and Gotland, and also by the great lakes of Central Sweden (Vänern, Mälaren, Hjälmaren). It is apparently much less frequent on the western coast of Sweden, where it has also been looked for (Eriksson, Hjortstam \& Ryvarden 1978: 941).

In Finland the fungus has been found in the southwestern part of the country (Varsinais-Suomi), in Kustavi, Kiperluoto and in Kakskerta, Prinkkala.

In France the species has been found three times in the southeastern part and once in the southwestern part (Drôme, Vaucluse and Dordogne: J. Boidin in litt.).

In Spain the species has been mentioned only once (on J. oxycedrus near La Mierla, Guadalajara: García-Manjón \& Moreno 1981). Surprisingly, it has also been collected in the Tianschan Mountains, NW 
Table 1 (Right). Spores of Peniophora junipericola. No. = number of the herbarium specimen in TAA; $\mathrm{Reg}=$ region of locality: $\mathrm{C}-$ Crimea, $\mathrm{E}-$ Estonia, $\mathrm{F}$ - France, L - Latvia, S - Finland, T - Tianschan. Mean spore size: $\mathrm{L}=$ length, $\mathrm{W}=$ width, $\mathrm{Q}=$ length/ width quotient, $\mathrm{V}=$ volume (cub $\mu \mathrm{m}), \mathrm{D}=$ equivalent spore diameter in $\mu \mathrm{m}$.

Caucasus (one sterile specimen) and on the Crimean peninsula, where it is common near Yalta, which is the only region of the Crimea studied by us.

The species has further been searched for in Norway, the Netherlands, West Germany, and many parts of the Soviet Union, but in vain.

Until we identified the specimens collected in the Crimea and Asia, we considered $P$. junipericola to be a representative of the subatlantic "floral" element. Most of the localities in Europe are situated in the region where the degree of phytogeographic oceanity is $\mathrm{OC} 1$ or in region $\mathrm{OC} 2$ near its boundary with $\mathrm{OC} 1$ (Jäger 1972). The localities in the Crimea, Caucasus and Tianschan, however, contradict such a conclusion. The distribution pattern of $P$. junipericola is much more similar to that of xerothermic species. The western islands of Estonia, where P. junipericola is common, are characterized by warm and dry summers, mild autumns and (compared with Central, East and South Estonia) fairly mild winters. However, the number of xerothermic Aphyllophorales is rather low in North and Central Europe; Phellinus torulosus (Pers.) Bourd. \& Galz. seems to be the only species whose distribution has been studied in detail in this respect.

The specimens of $P$. junipericola (outside Estonia and Latvia) studied by us:

Finland. Varsinais-Suomi: Kakskerta, Prinkkala, Kokkila, on dead branches of Juniperus, 19.VII.1934 Lauri E. Kari ("Peniophora laevigata (Fr.) Massee ", TUR 29836). Kustavi, Kiparluoto, S margin of Riihivainio, 12.XI.1989 I. Parmasto (TAA 126530).

U.S.S.R. Caucasus: Regio Krasnodar, distr. Gelendzhik, Archipo-Ossipovka, ad ramum emortuum Juniperi oxycedri frequentissime, E. Parmasto 24.IX.1966 (TAA 18848). Crimea: Livadia, Juniperus excelsa, ad ramum emortuum, 25.V.1989 V.P. Isikov (TAA 151719, 151729); Juniperus oxycedrus, ad ramum emortuum, 25.V.1989 I. Parmasto (TAA 151713, 151720, 151726, 151727). Kazakhstan: montes Tianschanici, Zailiiski Alatau, apud vallim fluvii Turgen, Juniperus semiglobatus, A. Raitviir 20.VI.1976 (TAA 63574).

\begin{tabular}{|c|c|c|c|c|c|c|}
\hline No. & Reg & $\mathrm{L}$ & W & Q & V & D \\
\hline 101327 & $\mathrm{E}$ & 8.86 & 2.87 & 3.09 & 51.1 & 4.61 \\
\hline 105455 & E & 8.90 & 2.88 & 3.09 & 51.7 & 4.62 \\
\hline 125779 & E & 9.03 & 2.93 & 3.08 & 54.3 & 4.70 \\
\hline 104077 & E & 9.11 & 3.10 & 2.94 & 61.0 & 4.88 \\
\hline 107238 & E & 9.17 & 2.83 & 3.24 & 51.7 & 4.62 \\
\hline LY8892 & $\mathrm{F}$ & 9.21 & 2.89 & 3.19 & 54.1 & 4.69 \\
\hline 105403 & L & 9.29 & 3.02 & 3.08 & 59.3 & 4.84 \\
\hline 52935 & E & 9.35 & 2.85 & 3.28 & 53.6 & 4.68 \\
\hline 151720 & C & 9.36 & 3.21 & 2.92 & 67.1 & 5.04 \\
\hline 104031 & E & 9.38 & 3.05 & 3.08 & 61.1 & 4.89 \\
\hline 126530 & S & 9.39 & 2.94 & 3.20 & 57.1 & 4.78 \\
\hline 105411 & L & 9.40 & 3.06 & 3.07 & 61.6 & 4.90 \\
\hline 150559 & E & 9.41 & 3.07 & 3.07 & 62.1 & 4.91 \\
\hline 112684 & $\mathrm{E}$ & 9.41 & 3.35 & 2.81 & 73.1 & 5.19 \\
\hline 112684 & E & 9.41 & 3.35 & 2.81 & 73.1 & 5.19 \\
\hline 125558 & E & 9.44 & 2.96 & 3.19 & 58.2 & 4.81 \\
\hline 105466 & E & 9.49 & 3.03 & 3.13 & 61.2 & 4.89 \\
\hline T29836 & S & 9.54 & 2.97 & 3.22 & 59.2 & 4.84 \\
\hline 150560 & $\mathrm{E}$ & 9.56 & 2.80 & 3.41 & 53.1 & 4.66 \\
\hline 97443 & E & 9.68 & 3.35 & 2.89 & 75.5 & 5.24 \\
\hline 97443 & E & 9.68 & 3.35 & 2.89 & 75.5 & 5.24 \\
\hline 104042 & E & 9.69 & 3.44 & 2.82 & 79.4 & 5.33 \\
\hline 104065 & E & 9.71 & 2.95 & 3.29 & 59.7 & 4.85 \\
\hline 63574 & $\mathrm{~T}$ & 9.73 & 3.02 & 3.23 & 62.5 & 4.92 \\
\hline 105470 & E & 9.75 & 3.04 & 3.21 & 63.4 & 4.95 \\
\hline 105398 & L & 9.77 & 2.99 & 3.27 & 61.6 & 4.90 \\
\hline 52923 & $E$ & 9.78 & 2.69 & 3.64 & 50.5 & 4.59 \\
\hline 105407 & L & 9.78 & 2.89 & 3.38 & 57.8 & 4.80 \\
\hline 105489 & L & 9.78 & 2.89 & 3.38 & 57.8 & 4.80 \\
\hline 104001 & $E$ & 9.79 & 3.05 & 3.21 & 64.1 & 4.97 \\
\hline 104026 & E & 9.81 & 3.34 & 2.94 & 76.2 & 5.26 \\
\hline 104014 & E & 9.89 & 3.20 & 3.09 & 71.0 & 5.14 \\
\hline 151729 & C & 9.89 & 3.21 & 3.08 & 71.4 & 5.15 \\
\hline 104078 & E & 9.93 & 3.17 & 3.13 & 70.0 & 5.11 \\
\hline 104009 & E & 9.93 & 3.02 & 3.29 & 63.9 & 4.96 \\
\hline 105469 & E & 9.95 & 3.06 & 3.25 & 65.7 & 5.01 \\
\hline 104027 & E & 9.96 & 3.44 & 2.90 & 81.9 & 5.39 \\
\hline 104033 & E & 9.96 & 3.04 & 3.28 & 64.9 & 4.99 \\
\hline 105467 & E & 9.97 & 2.93 & 3.40 & 60.6 & 4.87 \\
\hline 126436 & $\mathrm{E}$ & 10.01 & 3.07 & 3.26 & 66.5 & 5.03 \\
\hline 52923 & E & 10.01 & 3.34 & 3.00 & 78.0 & 5.30 \\
\hline 101959 & E & 10.03 & 2.87 & 3.49 & 58.7 & 4.82 \\
\hline 105421 & L & 10.03 & 2.96 & 3.39 & 62.2 & 4.92 \\
\hline 102837 & E & 10.05 & 3.17 & 3.17 & 71.0 & 5.14 \\
\hline 126432 & E & 10.07 & 3.10 & 3.25 & 68.2 & 5.07 \\
\hline 105464 & E & 10.13 & 3.04 & 3.33 & 66.2 & 5.02 \\
\hline 105408 & L & 10.15 & 3.14 & 3.23 & 70.5 & 5.13 \\
\hline 105409 & L & 10.16 & 3.05 & 3.33 & 66.8 & 5.03 \\
\hline 112685 & E & 10.16 & 3.50 & 2.90 & 86.5 & 5.49 \\
\hline 112685 & E & 10.16 & 3.50 & 2.90 & 86.5 & 5.49 \\
\hline 151726 & C & 10.19 & 3.19 & 3.19 & 72.9 & 5.18 \\
\hline 104024 & E & 10.21 & 3.29 & 3.10 & 77.5 & 5.29 \\
\hline 105465 & E & 10.21 & 2.98 & 3.43 & 64.3 & 4.97 \\
\hline 107270 & E & 10.32 & 2.88 & 3.58 & 61.0 & 4.88 \\
\hline 100787 & E & 10.34 & 3.32 & 3.11 & 79.9 & 5.34 \\
\hline 104016 & E & 10.36 & 3.34 & 3.10 & 81.0 & 5.37 \\
\hline 104030 & E & 10.46 & 3.22 & 3.25 & 76.4 & 5.27 \\
\hline 104017 & E & 10.46 & 3.53 & 2.96 & 90.9 & 5.58 \\
\hline 52940 & $\mathrm{E}$ & 10.51 & 3.32 & 3.17 & 81.4 & 5.38 \\
\hline 105402 & L & 10.69 & 3.05 & 3.50 & 70.7 & 5.13 \\
\hline 105462 & E & 10.80 & 3.05 & 3.54 & 71.5 & 5.15 \\
\hline 101779 & E & 11.02 & 3.59 & 3.07 & 99.4 & 5.75 \\
\hline 102838 & E & 11.56 & 3.61 & 3.20 & 106.0 & 5.87 \\
\hline
\end{tabular}




\section{Variability of spores}

We have taken 30 spore prints from freshly collected basidiocarps of $P$. junipericola to examine the variability of spore size and spore form in this species. In addition, spores from some herbarium specimens collected in France, the Caucasus and Finland were used. The spores were measured in 2 per cent $\mathrm{KOH}$ solution using an eyepiece micrometer at a magnification $\times 700$; 50 spores were measured from each spore sample. The results are given in Table 1 . The $90 \%$ expected tolerance limits of the means of all specimens and spore prints studied by us (calculated as described in Parmasto \& Parmasto 1987) are as follows: $\mathrm{L}=9.02-10.70 \mu \mathrm{m} ; \mathrm{W}=2.76-3.47 \mu \mathrm{m} ; \mathrm{Q}=$ 2.85-3.50; $\mathrm{D}=4.72-5.51 \mu \mathrm{m}$.

The spores of $P$. junipericola may be characterized as moderately variable: the coefficients of variability (CV) of mean spore length, width, length/ width quotient and volume (transformed into equivalent sphere diameter D) are $5.1 ; 6.8 ; 6.1$ and 5.5 . According to the Chi-square test and KolmogorovSmirnov test, the distribution curves of all these four data sets are approximately normal. According to the analysis of variance, the spore size and form do not differ significantly between the groups of specimens collected in different parts of Estonia, the Crimea, the Tianschan, France or Finland. There are no remark- able differences in other morphological characters, either.

Acknowledgements. The authors are greatly indebted to Dr. J. Boidin, Dr. J. Eriksson and Dr. J.I. Barkman for the information on the distribution of $P$. junipericola; to J. Boidin and Dr. Y. Mäkinen for spore prints and herbarium specimens; to Dr. A. Morton for permission to use his mapping program DMAP, and to Dr. N. Hallenberg for critical comments on the manuscript.

\section{References}

Eriksson, J., Hjortstam, K. \& Ryvarden, L. 1978: The Corticiaceae of North Europe 5. - Pp. 887-1047. Fungiflora, Oslo.

García-Manjón, J.L. \& Moreno, G. 1981: Estudios sobre Aphyllophorales 1. Fructificaciones sobre Juniperus. - An. Jard. Bot. Madrid 37:407-416.

Jäger, E.J. 1972: Comments on the history and ecology of continental European plants. In: Valentine, D.H. (ed.), Taxonomy, phytogeography and evolution, pp. 349-362. London \& New York.

Kaar, E. 1965: Kadakas - loopealsete ja packaljude küpress. — Eesti Loodus 8:69-75.

Parmasto, E. \& Parmasto, I. 1987: Variation of basidiospores in the Hymenomycetes and its significance to their taxonomy. - Bibl. Mycol. 115:1-168.

Received on 22 March 1991 